UDC $342.9+349.6$

DOI https://doi.org/10.32841/2307-1745.2019.42-2.16

\author{
Borysenko A. O., \\ PhD Student in the Department of Civil, Commercial and Environmental Law \\ National Technical University "Dniprovsk Polytechnic"
}

\title{
THE SYSTEM OF TAXATION OF ACTIVITIES IN THE FIELD OF USE OF NATURAL RESOURCES
}

\begin{abstract}
Summary. The article defines the system of taxation of activity in the sphere of use of natural resources in Ukraine. The author emphasized that the system of ensuring the efficient and safe use of natural resources includes many components, the leading among which is the creation of a proper mechanism for public management of this area and the legal bases for its functioning. The author substantiates that a comprehensive study of the problem of optimization of the taxation system for the use of mineral resources as a national wealth in Ukraine has not yet been carried out, which is required in accordance with the announced European integration vector for the development and implementation of European Union law. The purpose of the study is to establish a system of taxation of activities in the field of natural resources, to find ways to optimize it to improve its legal effectiveness. The economic methods of public administration in the field of natural resources use include: 1) payment for the use of natural resources and pollution arising from their use; 2) preferential lending of shortand long-term credits for the implementation of projects for ensuring the implementation of projects of rational use of natural resources; 3) exemption from taxation of activities related to the use of natural resources in the case of the implementation of production greening projects; 4) budgetary and extra-budgetary investments in the development of state and regional environmental funds. The author has determined that the purpose of taxation of activities related to the use of natural resources, including in the case of their pollution, is the formation of environmental funds, through which it is possible to finance the implementation of special measures for the restoration of natural resources and ensure the human right to a favourable environmental natural environment. It is determined that the experience of the Republic of Poland in implementing the legal regulation of the amount of environmental tax is positive, not in the amount fixed by law, but in the amount of directly caused damage to the environment and the corresponding natural resources. The conclusion of the study was justification of the expediency of introducing amendments to section 8 "Environmental tax" of the Tax Code of Ukraine for the ecological stimulation of rational use and conservation of natural resources, expanding the capacity of credit and financial support and assistance to economic entities in the implementation of measures for the rational use of natural resources through targeted special budget funds, as well as redistribution of tax payments between national budgets, the region local and local levels.
\end{abstract}

Key words: environmental tax, instrument, extrabudgetary trust fund, public administration, form.

Research problem. The system for ensuring the efficient and safe use of natural resources includes many components, the leading place among which is the creation of an appropriate mechanism for public administration of this area and the legal foundations of its functioning. The specified mechanism covers the entire process of using natural resources, from granting the right to use them to bringing those responsible for violating its rules to legal liability and terminating this right. It's enough to recall the numerous violations of the procedure for obtaining special permits for the use of natural resources in general, in particular in the field of subsoil use (spontaneous mining of amber, coal, etc.), Forest resources (mass destruction of forests, including protected areas of the Carpathian region), disposal in violation of environmental safety requirements for industrial wastes and the like. State policy in the field of the use of natural resources in Ukraine cannot be assessed as sufficiently effective, as the state of natural resources continues to deteriorate. According to official indicators, the state of the environment in about $20 \%$ of the territory of Ukraine is defined as unsatisfactory. As a result, an additional 30,000-35,000 people die each year, and economic damage reaches $10 \%$ of the gross domestic product. These circumstances indicate an extremely low level of effectiveness of the implementation of the public administration mechanism in the use of natural resources. In this regard, the development and improvement of the system of administrative and legal regulation of public administration in this area, as well as the proper theoretical understanding of its content and ways of improvement, are urgent.

Analysis of recent research and publications. The issues of optimizing the implementation of public administration have repeatedly been the subject of research by representatives of modern legal science. The scientific developments of Yu.A. Leges, A.A. Surilova [1, p. 30-33; 2, p. 99-103], where the forms and methods of ensuring the optimization of forms of public administration in the field of the use of natural resources in general, and in particular in the field of subsoil use, are established; L.A. Mironova [3], N.R. Kobetsky [4], where the features of the legal regulation of natural resource contractual relations are established; R.S. Kirina [5], V.I. Andrejtseva [6], established the basic principles of systematization of natural resource legislation. Separately, it is necessary to determine the research of VA Tulyantsev [7, p. 39-44], O.B. Zaichuk [8], the results of which are aimed at improving the formation of extrabudgetary trust funds, including through the collection of mandatory payments for the use of natural resources. However, a comprehensive study of the problem of optimizing the system of taxing activities for the use of subsurface resources as national wealth in Ukraine has not yet been carried out, which is required in accordance with the declared European integration vector of development and implementation of European Union legislation. 
The aim of the study is to establish a system of taxation of activities in the field of the use of natural resources, search for ways to optimize it to increase its legal effectiveness.

Statement of the main material. The main task of public administration is the combination of a system of rewards, material interest with coercion and punishment systems. This practice takes place in the global community. Public administration authorities in the field of the use of natural resources should establish accumulations of financing for environmental insurance at the expense of budgetary funds and funds for environmental management attracted from business entities. It is possible to establish a system of environmental insurance, establish a system of incentives, tax incentives for environmental costs; for the introduction of economical technologies, with environmentally friendly products and additional taxation and fines for pollution and wasteful use of natural resources. The means by which effective public administration in the field of the use of natural resources should be implemented is the legal regulation of this area and their conscientious implementation by all entities, use and manage natural resources.

The economic methods of public administration in the field of natural resources include: 1) fees for the use of natural resources and pollution arising from their use; 2) preferential lending of shortand long-term credits for the implementation of projects for ensuring the implementation of projects of rational use of natural resources; 3) exemption from taxation of activities related to the use of natural resources in the case of the implementation of production greening projects; 4) budgetary and extra-budgetary investment in the development of state and regional environmental funds [9, p. 39-41].

The purpose of taxation of activities related to the use of natural resources, including in the case of pollution, is the formation of environmental funds, through which it is possible to finance the implementation of special measures for the restoration of natural resources and the protection of human rights to a favorable environment.

Formation of environmental funds is carried out not only at the expense of natural resources, obtaining special permits or licenses for their use, or obtaining other types of administrative (public) services in the field of environmental resources, but also due to the introduction of taxation activities, which worsen the environment. In particular, in the Federal Republic of Germany the taxation of lubricating oils, crude oil and petroleum products was introduced [10, p. 71-82].

In the same way, a system of environmental taxes and levies has been built in the French Republic, Finland and Italy. Similarly, the fuel tax is the source of the creation of special environmental funds in the Netherlands. This tax covers $50 \%$ of the costs of the Ministry of Ecology, including the costs of preventing and compensating for damage, subsidizing the implementation of advanced advanced technologies for treatment and treatment, and financing the disposal of chemical waste [11, p. 272-277].

Economic incentives are also constantly used to encourage the implementation of environmental measures and the use of energy-saving resources. In particular, in the Federal Republic of Germany the vehicle tax is constantly adjusted and a more favorable annual tax regime is granted [12].

Among the means of public administration in the field of the use of natural resources, which are widely used in Western Europe, is the application of preferential taxation of investment activities aimed at reducing the negative impact on the environment. In the Kingdom of the Netherlands, in particular, tax benefits are applied in the amount of $10-15 \%$ of the total amount of environmental tax if the company introduces investments for the implementation of environmental measures. The Kingdom of Spain also introduced tax incentives of up to $30 \%$ for environmental investment activities [13, p. 272-277].

It should be emphasized that, depending on the degree and direction of environmental impact, it is necessary to choose economic instruments that should limit the negative impact and fulfill a stimulating function in the field of environmental protection and rational nature management. The economic instruments of public administration in the use of natural resources include: 1) preferential taxation, 2) subsidies, subsidies, grants; 3) soft loans; 4) budget and extrabudgetary funding.

It is determined that in today's conditions, the issue of providing public administration methods for using its natural resources with such functions as:

1) conducting in the prescribed manner environmental impact assessment (which is being implemented instead of the mechanism of state and public environmental review)

2) ensuring transparency of the mechanism of idle-license production;

3) maintaining national and regional cadastres of natural resources in electronic form, will fully ensure the implementation of the task of ensuring public access to environmental information;

4) the implementation of national and regional environmental monitoring;

5) the introduction of an integrated environmental assessment as a universal method for determining the degree of danger of activities associated with the special use of natural resources, setting tax rates for the results of such activities, setting norms and standards for the use of natural resources.

Noteworthy is the developed and implemented system of taxation of activities related to the use of natural resources. The taxation of activities related to the use of natural resources in foreign countries is carried out by making such types of mandatory payments as royalties, sovereign tax, special taxes on the profits of mining companies, differential rental payments, land tax, fees for the right to use subsoil resources, deductions for protection and recovery of mineral resources, excise tax, payment for emissions, sales tax, export tax and others. In this case, preference is given to taxation in a direct way, or to taxes of a "direct hand".

In particular, rent payers are, as a rule, users of natural resources. The most important direct taxes on natural resources include: rent, tax on access to natural resources, tax on extraction and exploration, as well as fees for the right to use natural resources, calculated per unit of leased territory. The rent is set at a nominal level in the first years of operation of the natural resource, but is gradually increasing in order to stimulate the tenant to develop its production. Royalty is a payment to the state for the right to use an exhaustive natural resource. It is calculated based on the gross income of the producer, and not on his net profit [14].

The system of payments for the use of natural resources in foreign countries also includes an "administrative fee", which is introduced to ensure the costs of monitoring the use of natural resources, registration and transfer to their owner, etc. In the first case, we are 
talking about taxes on natural resources, and in the second - about the fee for a license or real estate tax.

For example, the system of payments for the use of water resources in Western Europe consists of two main types of payments:

1) payments for water resources intended for the redistribution (withdrawal) of rent that arises from the water user in the process of exploitation of water resources (when determining them, they proceed from the value of the rental income and focus on the part that should be withdrawn from the water user)

2) payments aimed at maintaining the existing water management system. They are a tool for collecting the funds necessary to cover administrative costs for monitoring the operation of water resources and certain infrastructure costs (any license fees, etc.). Additional payments are withdrawn for services related to the assessment of water resources (laboratory analysis, registration and certification of documents, etc.). These payments go to a special fund designed to improve the quality of relevant services. Positive is the experience of the Republic of Poland in the implementation of legal regulation of the amount of environmental tax not in the fixed amount fixed by law, but in the amount of directly caused damage to the environment and the corresponding natural resources [15].

The purpose of taxation of activities related to the use of natural resources, including in the case of pollution, is the formation of environmental funds, through which it is possible to finance the implementation of special measures for the restoration of natural resources and the protection of human rights to a favorable environment.

Conclusions. Therefore, amendments to section 8 "Environmental tax" of the Tax Code of Ukraine for ecological stimulation of rational use and conservation of natural resources, expansion of opportunities of credit and financial support and assistance to economic entities in realization of measures for rational use of natural resources through special purpose funds budget, as well as the redistribution of tax payments between national, regional and local budgets.

\section{References:}

1. Легеза Ю.О. Поняття та види форм публічного управління у сфері використання природних ресурсів. Науковий вісник Херсонського державного університету. Серія «Юридичні науки». 2017. № 3. C. 30-33.

2. LehezaYu. \& Surilova O. Legal regulation of the application of economic mechanisms for ensuring the rational use of natural resources : the experience of foreign countries. Baltic Journal of Economic Studies. 2019. Vol. 5 (3). P. 99-103. Doi:10.30525/2256-0742/2019-5-3-99-103.

3. Миронова Л.А. Гражданско-правовые договоры в сфере природопользования : дисс. ... канд. юрид. наук : 12.00 .03 . Москва, 2003. $206 \mathrm{c}$.

4. Кобецька Н.Р. Дозвільне та договірне регулювання використання природних ресурсів в Україні : дис. ... докт. юрид. наук : 12.00.06. Київ : Нац. академія наук України ; Ін-т держави і права ім. В.М. Корецького, 2016. 424 с.

5. Кірін Р.С. Кодифікація законодавства про надра : дис. ... докт. юрид. наук : 12.00.06. Київ : Нац. академія наук України, Ін-т економіко-правових досліджень, $2016.374 \mathrm{c}$.

6. Андрейцев В.І. Екологічне право і законодавство суверенної України: проблеми реалізації державної екологічної політики : монографія. Дніпро : Нац. гірничий ун-т, 2011. 373 с.
7. Тулянцева В.А. Фінансово-правове регулювання діяльності позабюджетних цільових фондів. Jurnalul juridic național: teorie şi practică. 2015. № 3. Т. 2. С. 39-44.

8. Зайчук О.Б. Правовий статус централізованих позабюджетних цільових фондів : дис. ... канд. юрид. наук : 12.00.07. Київ, 2005. 239 c.

9. Бурик 3.М. Система методів державного регулювання сталого розвитку в Україні. Актуальні проблеми державного управління. 2016. № 1 (49). С. 37-44.

10. Маликова О.И. Управление охраной окружающей среды в Федеративной республике Германия. Вестник Московского университета. Серия «Экономика». 2001. № 1. Сер. 6. С. 71-82.

11. Мартиненко В.О. Досвід країн ЄС щодо сучасних механізмів управління охороною навколишнього середовища в Україні. Теорія та практика державного управління : зб. наук. праць. Вип. 1 (13). Харків : Вид-во ХарРІ НАДУ «Магістр», 2006. С. 272-277.

12. European Commission and Germany reach agreement on a fair and non-discriminatory road charging scheme / European Commission Press-release. Brussels, 1 December 2016. URL: http://europa.eu/ $\mathrm{rapid} /$ press-release_IP-16-4221_en.htm.

13. Хвесик М.А., Голян В.А. Інституціональна модель природокористування в умовах глобальних викликів : монографія. Київ : Кондор, 2007. $480 \mathrm{c}$.

14. Мандзик B.M. Світовий досвід справляння платежів за користування водними ресурсами. 25.08.2014. URL: http://economics-ofnature.net/uploads/arhiv/2008/Mandzyk.pdf.

15. Якушенко Л. Аналіз досвіду Європейського співробітництва щодо формування і втілення інституцій та інструментів екологічної політики : аналітична записка. Національний інститут стратегічних досліджень при Президентові Украӥни. 2014. URL: http://www.niss.gov.ua/articles/840/.

Борисенко А. О. Система оподаткування діяльності у сфері використання природних ресурсів

Анотація. У статті визначено систему оподаткування діяльності у сфері використання природних ресурсів в Україні. Автор підкреслив, що система забезпечення ефективного та безпечного використання природних ресурсів включає багато компонентів, провідним серед яких $\epsilon$ створення належного механізму управління громадськістю цією територією та правових основ її функціонування. Автор обгрунтовує, що всебічного дослідження проблеми оптимізації системи оподаткування використання мінеральних ресурсів як національного багатства в Україні ще не проведено, що потрібно відповідно до оголошеного вектора європейської інтеграції для розвитку й імплементація права Європейського Союзу. Мета дослідження - налагодити систему оподаткування діяльності в галузі природних ресурсів, знайти шляхи іï оптимізації для підвищення її юридичної ефективності. Економічні методи державного управління у сфері використання природних ресурсів включають: 1) плату за використання природних ресурсів і забруднення, що виникають унаслідок їх використання; 2) пільгове кредитування коротко- та довгострокових кредитів на реалізацію проектів для забезпечення реалізації проектів раціонального використання природних ресурсів; 3) звільнення від оподаткування діяльності, пов'язаної 3 використанням природних ресурсів у разі реалізації проектів екологічного озеленення; 4) бюджетні та позабюджетні інвестиції в розвиток державних і регіональних екологічних фондів. Автор визначив, що метою оподаткування діяльності, пов'язаної з використанням природних ресурсів, у тому числі в разі їх забруднення, 
$\epsilon$ формування екологічних фондів, за допомогою яких можна фінансувати реалізацію спеціальних заходів щодо відновлення природні ресурси та забезпечувати право людини на сприятливе навколишнє природне середовище. Визначено, що досвід Республіки Польща щодо здійснення правового регулювання розміру екологічного податку є позитивним не в розмірі, визначеному законом, а в розмірі безпосередньо заподіяної шкоди навколишньому середовищу та відповідним природним ресурсам. Висновок дослідження $є$ обгрунтуванням доцільності внесення змін до розділу 8 «Екологічний податок» Податкового кодексу України щодо екологічного сти- мулювання раціонального використання та збереження природних ресурсів, розширення можливостей кредитно-фінансової підтримки й допомоги суб'єктам господарювання в здійсненні заходів щодо раціонального використання природних ресурсів за рахунок цільових спеціальних бюджетних коштів, а також перерозподілу податкових платежів між національними бюджетами, регіональним місцевим і місцевим рівнями.

Ключові слова: екологічний податок, інструмент, позабюджетний цільовий фонд, державне управління, форма. 